\title{
Vigor Evaluation of Fifteen Months Stored Delinted Gossypium hirsutum L. Varieties Picked at Different Intervals
}

\author{
A. Dayal ${ }^{1 *}$, V.S. Mor ${ }^{2}$, O.S. Dahiya ${ }^{2}$ and R.C. Punia ${ }^{2}$ \\ ${ }^{1}$ Department of Genetics and Plant Breeding, Sam Higginbottom University Agriculture \\ Technology and Sciences, India \\ ${ }^{2}$ Department of Seed Science and Technology, CCS Haryana Agricultural University, India \\ *Corresponding author
}

\section{A B S T R A C T}

\begin{tabular}{|l|}
\hline Ke y w or d s \\
Picking, Storage, \\
vigor, Seed \\
germination, Vigor \\
indices
\end{tabular}

\section{Introduction}

A key component of the performance of crop seeds is the complex trait of seed vigor. Crop yield and resource use efficiency depend on successful plant establishment in the field and it is the vigor of seeds that defines their ability to germinate and establish seedlings rapidly, uniformly across diverse environmental conditions. Our knowledge of the regulation of seed vigor has developed in recent times, but understanding the basis of variation and therefore seed performance during the establishment of crops remains limited.

\begin{abstract}
Seed ageing is influenced by two factors moisture and temperature. The deterioration of the stored seed is a natural phenomenon and the seeds tend to lose viability even under ideal storage conditions. The present study was carried out in the Department of Seed Science and Technology Section, CCS Haryana Agricultural University, Hisar, India. This study aimed at evaluating efficiency of different pickings of cotton seed vigor potential dung storage. Thereby, three American cotton varieties H-1098 (I), H-1117 and H-1236 ine taken into account, were picked at different intervals and after ginning and delinting, initial seed vigor evaluation was done and seeds were stored under controlled condition at
$20^{\circ} \mathrm{C}$ with 6 per cent moisture content for fifteen months. Evaluations of germination per cent, seedling length, seedling weight, vigor indices were performed after five, ten and fifteen months of storage $(5,10,15$ months). It was observed that seed samples of second pick stored seed showed higher vigor followed by first pick stored sample whereas minimum was recorded under third pick stored sample.
\end{abstract}

The longevity of a seed lot is the length of time the seeds remain viable after reaching physiological maturity (Delouche, 1968). For seed storage purposes, longevity is used synonymously with storability. To preserve the initial seed quality, seeds must be properly stored between the time of harvest and the planting of a subsequent crop. Delouche (Delouche, 1968) defined the total seed storage period as comprising segments of bulk storage, which is the period from harvest through packaging including conditioning. Packaged storage was defined as the period between packaging and distribution; and 
distribution storage covered the period between sales to farmers, including time at wholesalers and retail outlets.

Seed ageing leads to reduction in seed quality, performance and stand establishment. In spite of countless investigations and speculations, we do not know the cause of loss in viability during storage (Presley, 1958), however, it is clear that most functional macromolecules, proteins, nucleic acids and lipids undergo changes during seed deterioration which ultimately precede death. Lipid auto oxidation has also been suggested to be one of the causes of seed ageing (Wang et al., 1990) which involve the production of free radicals.

Once seed deterioration has happened, this catabolic process cannot be reversed. It is a sequence of events beginning with a chain of biochemical events, predominantly membrane damage and impairment of biosynthetic reactions, and then the resulting losses of various seed performance attributes, starting with reduced germination rate, reduced field emergence, increased numbers of abnormal seedlings and finally seed death.

Seed deteriorates through normal physiological reactions and changes that occur within the seed over time. These changes result in the accumulation of deleterious byproducts that increase the seed's vulnerability to external challenges and decrease the ability of the seed to survive (Justice and Bass, 1978).

This process is inevitable and irreversible and only its rate can be controlled (Delouche, 1968). The process of deterioration, therefore, involves several physiological and structural changes within seed. Structural changes involve membrane permeability, proteins, sugars, nucleic acids, fatty acids and volatile substances, while physiological processes involve enzyme activity, respiratory competence, lipid peroxidation and physiological repair mechanisms (Priestley et al., 1980; Vertucci and Roos, 1990). According to (Trawatha et al., 1995) optimum protocols for seed storage must take into account the chemical composition of the seed, the physiological status of the seed, and the physical status of water within the seed. Two models of seed deterioration have been proposed (Vertucci and Roos, 1990).

This study was set to investigate the influence of various pickings on storability and vigor potential of American cotton varieties. The influence of different picked materials under controlled storage condition on seed vigor and germination over time. The experiment was laid in a complete randomized design with three replicates.

\section{Materials and Methods}

Two year study to evaluate the effect of pickings with fifteen days intervals was conducted on three Gossypium hirsutum L. varieties. Seeds were collected from the Cotton Section, Department of Genetics and Plant Breeding, CCS Haryana Agricultural University.

Different cotton varieties were sown in Randomized Block Design (RBD) with three replications during the month of April 201213 and 2013-14 in the cotton section field research area. The non-experimental rows were also maintained to avoid border effects. Recommended agronomic package and practices were followed to grow good and healthy crop.

The observations were recorded on seeds collected from various pickings. Fifteen plants were tagged for picking treatments and three bulk samples of each treatment /variety/replication were ginned and delinted separately. The pickings were started after 50 
percent boll opening and all the three pickings in each variety were taken with 15 days interval and evaluated for seed quality in laboratory of Department of Seed Science and Technology in completely randomized design with following observations.

\section{Seed lots (P) three of each pickings in three American cotton varieties}

Gossypium hirsutum: H-1098-(I), H-1117, H1236 ,

Seed moisture content (\%) of above fresh seeds at each picking stage were estimated by hot air oven method $\left(80 \pm 1^{\circ} \mathrm{C}\right.$ for $\left.24 \mathrm{~h}\right)$ and expressed in percentage.

Seed weight (g) of 100 seeds (replicated thrice) of each variety and each picking was recorded and expressed in $\mathrm{g}$.

Seed density (g/cc) from each sample was taken after weighing seeds on electronic balance than after dipping it in toluene solution.

Weight of 100 seeds

Seed density $(\mathrm{g} / \mathrm{cc})$ = -----------------------------

Volume of displaced seed (CC)

Standard germination (\%) as per ISTA, 2011

Final count was recorded on 12 th day (ISTA, 2011). Normal seedlings were expressed as percent germination.

Seedling length $(\mathrm{cm})$ of ten randomly selected normal seedlings was recorded and average seedling length was expressed in centimeters (cm).

Dry weight $(\mathrm{mg})$ ten randomly taken normal seedlings whose length was measured were dried in a hot air oven for $24 \mathrm{~h}$ at $103 \pm 1^{\circ} \mathrm{C}$.

\section{Vigour index -I \& II}

Vigour Index $-\mathrm{I}=$ Standard germination $(\%) \times$ average seedling length $(\mathrm{cm})$

Vigour Index-II=Standard germination $(\%) \times$ average seedling dry weight (mg)

Electrical conductivity test $\left(\mu S \mathrm{~cm}^{-1} \mathrm{~g}^{-1}\right)$ as per ISTA, 1999

Three replicates of 50 normal seeds were soaked in a $100 \mathrm{ml}$ beaker containing $75 \mathrm{ml}$ of distilled water and kept at $25^{\circ} \mathrm{C}$. The leachetes were measured after $24 \mathrm{~h}$ with systronic conductivity meter 306 and it was expressed as $\mu \mathrm{Sm}^{-1} \mathrm{~g}^{-1}$.

\section{Results and Discussion}

The experiment result showed significant difference between different picked sored seeds and varieties on seed germination percent and vigor. Germination and seed vigor percentage was found to decrease with increase in storage duration. The mean germination and vigor irrespective of various pick stored seeds samples, was found to decrease continuously from initial 75.52 to $64.3 \%$ after 15 months of storage respectively. In the present study, second pick stored samples seeds recorded higher seed germination ( 81.11 to $68.56 \%$ ) throughout the storage period of fifteen months. The second pick stored sample in sealed plastic containers had the highest seed germination per cent $81.11 \%$ (after five months) which declined to 68.56 (after fifteen months) \% whereas minimum germination percent found in third picked stored seeds which was $67.11 \%$ after five months and declined to $58.44 \%$ after fifteen months of storage. During deterioration, vigour is the first component of seed quality, which is lost, this is followed by a loss of germination capacity and viability as reported by (Tilebeni et al., 2011). Second 
picking seeds though decrease in vigour showed better performance during storage than both first and third picking stored seeds. Germination of the seeds observed decreasing progressively with ageing. Decreasing of germination per cent in aged seeds can be due to reduction of $\alpha$ - amylase activity and carbohydrate contents (Bailly et al., 2004) or denaturation of proteins (Nautiyal et al., 1985) or it may be related to chromosomal aberrations that occur under long storage conditions (Akhter et al., 1992). The main mechanisms for the reduced germination as a result of seed deterioration are not known, but some studies showed that lipid peroxidation caused by oxidative damage can lead to inactivation and/or depletion of key enzymes of recipient protein transport or ion channels, as well as impairment of RNA and DNA synthesis (Basra et al., 2003; Lehner et al., 2008; Murthy et al., 2003).

Maximum seedling length $35.97 \mathrm{~cm}$ was observed in second pick stored sample compared to other stored samples. Minimum $31.14 \mathrm{~cm}$ was found in third picked stored samples. During storage for fifteen months continuous decline in seedling length was observed.

After fifteen months of storage maximum seedling length $27.43 \mathrm{~cm}$ was observed in second pick stored samples and minimum $22.04 \mathrm{~cm}$ was observed in third pick stored samples whereas $23.93 \mathrm{~cm}$ was observed in first pick stored samples after fifteen months of storage. Seedling weight also found decreasing in all pick stored samples and among all cotton varieties. But maximum seedling weight $0.392 \mathrm{mg}$ was observed in second pick stored samples and minimum $0.338 \mathrm{mg}$ in third pick stored samples after five months of storage. After fifteen months of controlled storage maximum seedling weight $0.303 \mathrm{mg}$ was found in second pick stored sample and minimum $0.252 \mathrm{mg}$ observed in third pick stored samples after fifteen months of storage. Among all pickings second pick showed better seedling weight and seedling dry weight, which indicated less vigour loss in physiological matured seeds during storage. Reduction in seedling length and seedling dry weight may be due to decrease in mobilization of reserve substances during germination of the stored seeds (Dhakal and Pandey, 2001). Earlier reports have shown that storage could cause depletion of important nutrient reserves (Murthy et al., 2003). Ageing led to decrease in seedling length and seedling dry weight which is confirmed with the earlier findings of (30) in okra, (Khatun et al., 2009) in lentil, (Sun et al., 2007) in cotton and (Azadi and Younesi, 2013) in sorghum.

Varietal differences during storage in the present study were highly significant. Among the American cotton varieties, $\mathrm{H}-1117$ showed poor results than other two varieties $\mathrm{H}-1098$ (I) and H-1236. H- 1098 (I) decreased from 3120 vigor indices after five months of storage to 2185 after fifteen months of storage in vigor indices. It was however, observed that all varieties vigor index fell after fifteen months of storage.

After five months of storage maximum vigor index I, II was found in second pick stored samples 2918, 31.78 whereas after fifteen months it declined to 1885 and 20.83 in second pick stored samples. Minimum vigor index was observed in third pick 2096, 22.75 after five months of storage which declined to 1295, 14.74 after fifteen months of storage. Results are in conformity with the findings of (14). Reported a reduction in seedling dry mass after different periods of accelerated ageing on seeds of different varieties of lentil (Lens culinaris Medikus) (Makkawi and Gastel, 2006). Similar findings were reported by (Wilson and McDonald, 1986) in okra, (Dahiya et al., 1997) in chickpea and (Dayal et al., 2014) (Table 1). 
Table.1 Effect of storage on seed quality parameters after five, ten and fifteen months of storage

\begin{tabular}{|c|c|c|c|c|c|c|c|c|c|c|c|c|c|}
\hline & \multicolumn{5}{|c|}{ FIVE MONTHS } & \multicolumn{4}{|c|}{ TEN MONTHS } & \multicolumn{4}{|c|}{ FIFTEEN MONTHS } \\
\hline \multirow{7}{*}{$\begin{array}{c}\text { Germination } \\
(\%)\end{array}$} & & P1 & $\mathbf{P 2}$ & P3 & MEAN & P1 & $\mathbf{P 2}$ & P3 & MEAN & P1 & $\mathbf{P 2}$ & P3 & MEAN \\
\hline & H-1098(I) & 80 & 82 & 69.67 & 77.22 & 75 & 77.67 & 66 & 72.89 & 68.33 & 70.33 & 61.67 & 66.78 \\
\hline & H-1117 & 77 & 80 & 64.01 & 73.67 & 70 & 72.33 & 60.67 & 67.67 & 62.67 & 66 & 56.33 & 61.67 \\
\hline & H-1236 & 78 & 81.33 & 67.67 & 75.67 & 71.33 & 73.67 & 63 & 69.33 & 66.67 & 69.33 & 57.33 & 64.44 \\
\hline & MEAN B & 78.33 & 81.11 & 67.11 & 75.52 & 72.11 & 74.56 & 63.22 & 69.96 & 65.89 & 68.56 & 58.44 & 64.3 \\
\hline & CD & \multicolumn{4}{|c|}{$\mathrm{V}=0.998, \mathrm{P}=0.998, \mathrm{VxP}=1.729$} & \multicolumn{4}{|c|}{$\mathrm{V}=0.792, \mathrm{P}=0.792, \mathrm{VxP}=\mathrm{N} / \mathrm{A}$} & \multicolumn{4}{|c|}{$\mathrm{V}=0.859, \mathrm{P}=0.859, \mathrm{VxP}=1.488$} \\
\hline & SeM & \multicolumn{4}{|c|}{$\mathrm{V}=0.333, \mathrm{P}=0.333, \mathrm{VXP}=0.577$} & \multicolumn{4}{|c|}{$\mathrm{V}=0.264, \mathrm{P}=0.264, \mathrm{VxP}=0.458$} & \multicolumn{4}{|c|}{$\mathrm{V}=0.287, \mathrm{P}=0.287, \mathrm{VxP}=0.497$} \\
\hline \multirow{6}{*}{$\begin{array}{l}\text { Seedling } \\
\text { Length } \\
\text { (cm) }\end{array}$} & H-1098(I) & 35.17 & 38.05 & 35.59 & 36.27 & 31.64 & 33.46 & 30.68 & 31.93 & 28.26 & 31.07 & 26.62 & 28.65 \\
\hline & H-1117 & 31.34 & 34.85 & 28 & 31.4 & 27.87 & 30.37 & 24.8 & 27.68 & 21.91 & 23.94 & 19.18 & 21.68 \\
\hline & H-1236 & 32.9 & 35.01 & 29.82 & 32.57 & 28.77 & 30.67 & 25.85 & 28.43 & 21.62 & 27.26 & 20.28 & 23.05 \\
\hline & MEAN B & 33.13 & 35.97 & 31.14 & 33.41 & 29.43 & 31.5 & 27.11 & 29.35 & 23.93 & 27.43 & 22.02 & 24.46 \\
\hline & CD & \multicolumn{4}{|c|}{$\mathrm{V}=0.885, \mathrm{P}=0.885, \mathrm{~V} \times \mathrm{P}=1.533$} & \multicolumn{4}{|c|}{$\mathrm{V}=0.613, \mathrm{P}=0.613, \mathrm{~V} \times \mathrm{P}=1.061$} & \multicolumn{4}{|c|}{$\mathrm{V}=0.805, \mathrm{P}=0.805, \mathrm{~V} \times \mathrm{P}=1.395$} \\
\hline & SeM & \multicolumn{4}{|c|}{$\mathrm{V}=0.296, \mathrm{P}=0.296, \mathrm{~V} \times \mathrm{P}=0.512$} & \multicolumn{4}{|c|}{$\mathrm{V}=0.205, \mathrm{P}=0.205, \mathrm{~V} \times \mathrm{P}=0.354$} & \multicolumn{4}{|c|}{$\mathrm{V}=.269, \mathrm{P}=0.269, \mathrm{~V} \times \mathrm{P}=0.460$} \\
\hline \multirow{6}{*}{$\begin{array}{l}\text { Seedling } \\
\text { weigth } \\
\text { (mg) }\end{array}$} & H-1098(I) & 0.387 & 0.405 & 0.372 & 0.388 & 0.373 & 0.398 & 0.361 & 0.377 & 0.323 & 0.334 & 0.266 & 0.308 \\
\hline & H-1117 & 0.346 & 0.385 & 0.308 & 0.346 & 0.339 & 0.37 & 0.304 & 0.338 & 0.256 & 0.279 & 0.249 & 0.262 \\
\hline & H-1236 & 0.375 & 0.386 & 0.334 & 0.365 & 0.365 & 0.379 & 0.324 & 0.356 & 0.28 & 0.296 & 0.241 & 0.272 \\
\hline & MEAN B & 0.369 & 0.392 & 0.338 & 0.366 & 0.359 & 0.382 & 0.33 & 0.357 & 0.286 & 0.303 & 0.252 & 0.281 \\
\hline & CD & \multicolumn{4}{|c|}{$\mathrm{V}=0.006, \mathrm{P}=0.006, \mathrm{~V} \times \mathrm{P}=0.011$} & \multicolumn{4}{|c|}{$\mathrm{V}=0.004, \mathrm{P}=0.004, \mathrm{~V} \times \mathrm{P}=0.006$} & \multicolumn{4}{|c|}{$\mathrm{V}=0.003, \mathrm{P}=0.003, \mathrm{~V} \times \mathrm{P}=0.005$} \\
\hline & SeM & \multicolumn{4}{|c|}{$\mathrm{V}=.002, \mathrm{P}=0.002, \mathrm{~V} \times \mathrm{P}=0.004$} & \multicolumn{4}{|c|}{$\mathrm{V}=0.001, \mathrm{P}=0.001, \mathrm{~V} \times \mathrm{P}=0.002$} & $\mathrm{~V}=.0$ & $1, \mathrm{P}=0.0$ & $1, \mathrm{~V} \times \mathrm{I}$ & $=0.002$ \\
\hline VIGOR I & H-1098(I) & 2813 & 3120 & 2479 & 2804 & 2373 & 2599 & 2025 & 2332 & 1,931 & 2,185 & 1,641 & 1,919 \\
\hline & H-1117 & 2413 & 2788 & 1792 & 2331 & 1951 & 2197 & 1505 & 1884 & 1,373 & 1,581 & 1,080 & 1,345 \\
\hline & H-1236 & 2566 & 2847 & 2017 & 2477 & 2053 & 2259 & 1628 & 1980 & 1,442 & 1,890 & 1,163 & 1,498 \\
\hline & MEAN B & 2597 & 2918 & 2096 & 2537 & 2125 & 2352 & 1719 & 2065 & 1,582 & 1,885 & 1,295 & 1,587 \\
\hline & CD & $\mathrm{V}=7$. & $0, \mathrm{P}=67$. & $0, \mathrm{~V} \times \mathrm{F}$ & 116.73 & $\mathrm{~V}=4$ & $13, \mathrm{P}=47$ & $13, \mathrm{~V} \times$ & $\mathrm{P}=\mathrm{N} / \mathrm{A}$ & $\mathrm{V}=5$ & $2, \mathrm{P}=55$. & $92, \mathrm{~V} \times$ & $=96.86$ \\
\hline & SeM & $\mathrm{V}=2$. & $1, \mathrm{P}=22$ & $51, V \times$ & $=38.99$ & $\mathrm{~V}=5$ & $4, \mathrm{P}=15$. & $4, \mathrm{~V} \times \mathrm{I}$ & $=27.26$ & $\mathrm{~V}=8$. & $8, \mathrm{P}=18$ & $58, \mathrm{~V} \times 1$ & $=32.35$ \\
\hline VIGOR II & H-1098(I) & 30.93 & 33.18 & 25.92 & 30.01 & 28 & 30.91 & 23.83 & 27.58 & 22.05 & 23.52 & 16.38 & 20.65 \\
\hline & H-1117 & 26.66 & 30.79 & 19.71 & 25.72 & 23.73 & 26.79 & 18.44 & 22.99 & 16.07 & 18.43 & 14.03 & 16.18 \\
\hline & H-1236 & 29.25 & 31.4 & 22.63 & 27.76 & 26.04 & 27.92 & 20.43 & 24.8 & 18.66 & 20.54 & 13.8 & 17.67 \\
\hline & MEAN B & 28.95 & 31.79 & 22.75 & 27.83 & 25.92 & 28.54 & 20.9 & 25.12 & 18.93 & 20.83 & 14.74 & 18.17 \\
\hline & CD & $V=.5$ & $0, \mathrm{P}=0.5$ & $30, \mathrm{~V} \times$ & $=0.918$ & $\mathrm{~V}=.3$ & $1, \mathrm{P}=0.3$ & $31, \mathrm{~V} \times \mathrm{I}$ & $=0.660$ & $\mathrm{~V}=.35$ & $3, \mathrm{P}=0.3$ & $3, \mathrm{~V} \times \mathrm{P}$ & $=0.611$ \\
\hline & SeM & $V=.1$ & $7, \mathrm{P}=0.1$ & $77, \mathrm{~V} \times$ & $=0.307$ & $V=.1$ & $7, \mathrm{P}=0.12$ & $7, \mathrm{~V} \times \mathrm{F}$ & $=0.220$ & $\mathrm{~V}=0.1$ & $18, \mathrm{P}=0$. & $18, \mathrm{~V} \times$ & $=0.204$ \\
\hline $\mathrm{EC}$ & H-1098(I) & 0.332 & 0.352 & 0.351 & 0.345 & 0.404 & 0.391 & 0.443 & 0.412 & 0.486 & 0.456 & 0.494 & 0.479 \\
\hline$\left(\mu \mathrm{S} \mathrm{cm}{ }^{-1} \mathrm{~g}^{-1}\right)$ & H-1117 & 0.321 & 0.343 & 0.341 & 0.335 & 0.432 & 0.404 & 0.479 & 0.438 & 0.532 & 0.509 & 0.567 & 0.536 \\
\hline & H-1236 & 0.401 & 0.437 & 0.409 & 0.416 & 0.438 & 0.396 & 0.471 & 0.435 & 0.521 & 0.486 & 0.542 & 0.516 \\
\hline & MEAN B & 0.351 & 0.377 & 0.367 & 0.365 & 0.425 & 0.397 & 0.464 & 0.428 & 0.513 & 0.483 & 0.534 & 0.51 \\
\hline & CD & $\mathrm{V}=.0$ & $2, \mathrm{P}=0 . \mathrm{C}$ & $02, \mathrm{~V} \times$ & $=0.004$ & $\mathrm{~V}=.0$ & $7, \mathrm{P}=0.0$ & $7, \mathrm{~V} \times \mathrm{I}$ & $=0.012$ & $\mathrm{~V}=.0$ & $5, \mathrm{P}=0.0$ & $5, \mathrm{~V} \times 1$ & $=0.009$ \\
\hline & SeM & $\mathrm{V}=0$. & $01, P=.0$ & $1, \mathrm{~V} \times \mathrm{I}$ & $=0.001$ & $\mathrm{~V}=.0$ & $2, \mathrm{P}=0.0$ & $2, \mathrm{~V} \times \mathrm{I}$ & $=0.004$ & $\mathrm{~V}=.0$ & $2, \mathrm{P}=0.0$ & $2, \mathrm{~V} \times$ & $=0.003$ \\
\hline
\end{tabular}

The Electrical Conductivity of seed leachates increased in all varieties with increase in duration of storage. These results are similar to the results obtained in seeds of cotton by Presley (1958). Minimum leakage of electrolytes $0.351 \mu \mathrm{S} \mathrm{cm} \mathrm{cm}^{-1}$ were observed in first pick stored sample whereas maximum found in second pick stored sample $0.377 \mu \mathrm{S}$ $\mathrm{cm}^{-1} \mathrm{~g}^{-1}$ after five months of storage. Maximum electrical conductivity $0.534 \mu \mathrm{S}$ $\mathrm{cm}^{-1} \mathrm{~g}^{-1}$ was observed in third pick stored sample whereas minimum $0.483 \mu \mathrm{S} \mathrm{cm}^{-1} \mathrm{~g}^{-1}$ observed in second pick stored sample. Membrane disruption is one of the main 
reasons of seed deterioration as a result, seed cells are not able to retain their normal physical condition and functioning, which in turn resulted in increased leaching of electrolytes. Effect of storage time period was significant on leakage of electrolytes in all varieties. Leakage of electrolytes increased with increase in storage period. It was studied that under storage, enhancement in leakage of electrolyte was observed in all pickings but enhancement of leakage was high in third pick stored sample in comparison to other picking sample in both American cotton varieties. Enhancement of leakage was due to alterations in the membranes of aged seeds which led to electrolyte leakage. Cell expansion was reduced by ageing to a greater extent comparing to cell division as reported by (Bingham and Merritt, 1999). During ageing there was destruction in the membrane which reduces its vigour (Walters, 1998) because of the destruction of the membrane system, many electrolytes flowed out of cells, so the vigor of seed reduced. Seed deterioration leads to lipid peroxidation that subsequently causes membrane perturbation (Dhakal and Pandey, 2001) and increase in free fatty acid which destroy seed (Goel et al., 2003). The membrane integrity lost by damage of phospholipids leads to increased membrane permeability and exit of electrolytes and other substances, such as enzymes, from cells (Yadav et al., 2001). Results were in conformity with earlier findings of (Dhakal and Pandey, 2001) in cotton (Panobianco et al., 2007) in pea seeds in comman bean (Palabiyik and Peksen, 2008).

\section{Acknowledgement}

The Authors are sincerely grateful to staff members of Department of Seed Science and Technology and Head Cotton Section, Department of GPB, CCS Haryana Agricultural University and Government of
Haryana and GOI for providing the necessary facilities for completing the research work.

\section{References}

Akhter, F.N., Kabir, G., Mannan, M.A. and Shaheen, N.N. (1992). Aging effect of wheat and barley seeds upon germination mitotic index and chromosomal damage. Journal Islam Academics Science. 5: 44- 48.

Aldehyde levels during storage. Crop Science, 35: 1415-1422

Azadi M.S. and Younesi E. (2013). The Effects of Storage on Germination Characteristics and Enzyme Activity of Sorghum Seeds. Journal. of Stress Physiology and Biochemistry. 9 (4): 289 - 298.

Bailly, C. Leymarie, J., Lehner, A., Rousseau, S., Come, D. and Corbineau, F. (2004). Catalase activity and expression in developing sunflower seeds as related to drying. Journal. Experimental Botany. 55: 475-483.

Basra, S. M. A., Ullah, E., Warriach, E. A., Cheema, M. A. and Afzal, I. (2003). Effect of storage on growth and yield of primed canola seeds (Brassica napus). International Journal Agriculture Biology. 5: 117-120.

Bingham, I. J. and Merritt, D. J. (1999). Effects of seed aging on early post-germination root extension in maize: A spatial and histological analysis of the growth-zone. Seed Science Technology, 27: 151-162.

Dahiya, O.S., Tomer, R.P.S. and kumar, A. (1997). Evaluation of viability and vigour parameters with respect to field emergence in chickpea (Cicer arietinum L.) Seed Research, 25: 19- 24.

Dayal, A., Rangare, N. R., Kumar, A. and Kumari, M. (2014). Effect of physiological maturity on seed quality 
of maize (Zea mays L.) Forage Research, 40 (1): 1- 6.

Delouche, J.C. (1968). American in The Proc. $23^{\text {rd }}$ corn and sorghum Res. Conf. Seed Trade Assn. Washington D.C. Physiology of seed storage $83-90$.

Dhakal, M.R. and Pandey, A.K. (2001) Storage potential of niger (Guizotia abyssinica) seeds under ambient conditions, Seed Science and Technolology, 29: 205 - 213.

Goel, A., Goel, A.K. and Sheoran, I.S. (2003). Changes in oxidative stress enzymes during artificial ageing in cotton (Gossypium hirsutum L.) seeds. Journal. Plant Physiology. 160. 1093 1100.

ISTA. 2011. International Rules for Seed Testing. Chapter 5: the Germination Test. ISBN 978-3-906549-53-8. International Seed Testing Association, Baserdorf, Switzerland.

Justice, O. L., and L. N. Bass. 1978. Principles and Practices of Seed Storage. USDA Agricultural Handbook 506.

Kalsa, K.K., Tomer, R.P.S. and Abebie, B. (2011). Effects of storage duration and hydro-priming on seed germination and vigour of common vetch. Journal. of Science and Development. 1(1): 65 - 73.

Khatun, A., Kabir, G. and Bhuiyan, M. A. H. (2009). Effect of harvesting stages on the seed quality of lentil (Lens culinaris L.) during storage. Bangladesh Journal. Agrilculture Research.34 (4): 565-576.

Lehner, A., Mamadou, N., Poels, P., Côme, D., Bailly, C., Corbineau, F., (2008) Changes in soluble carbohydrates, lipid peroxidation and antioxidant enzyme activities in the embryo during aging in wheat grains. Journal of Cereal Science, 47 (3): 555-565.

Makkawi, M. and Gastel, A.J.G. (2006). Effect of accelerated ageing on germination and vigour of lentil (Lens culinaris Medikus) seed. Journal of New Seeds, 8: 87 - 97.

Murthy, U., Kumar, M.N. and Sun, W.Q. (2003). Mechanisms of seed ageing under different storage conditions for Vigna radiata (L.) Wilczek: lipid peroxidation, sugar hydrolysis, Maillard reactions and their relationship to glass state transition. Journal Experimental Botany, 384: 1057-1067.

Nautiyal. A.R, Thapliyal, A.P., Purohit, A.N. (1985). Seed viability. IV. Protein changes: Accompanying loss of viability in Shorea robusta. Seed Science Technology. 13: 83-86.

Palabiyik, B. and Peksen, E. (2008). Effects of Seed Storage Periods on Electrical Conductivity of Seed Leakage, Germination and Field Emergence Percentage in Common Bean (Phaseolus vulgaris L.). Asian Journal of Chemistry, 20(4): 3033-3041.

Panobianco, M., Vieira, R.D., Perecin, D. (2007). Electrical conductivity as an indicator of pea seed aging of stored at different temperatures. Scientia Agricola 64: 119-124.

Presley, J.T. 1958. Relation of protoplast permeability to cotton seed viability and predisposition to seedling disease. Dis. Reporter. 42: 852

Priestley, D.A., McBride, M.B. and Leopold, A.C., 1980. Tocopherol and organic free radical levels in soybean seeds during natural and accelerated aging. Plant Physiology, 66: 715-719.

Sun, Q., J. Wang, B. Sun. 2007. Advances on seed vigor physiology and genetic mechanisms. Agriculture Science, China 6:1060-1066.

Tilebeni, G., Zeinali, E. and Tavassoli, A. (2011). Effects of Seed Ageing on Heterotrophic Seedling Growth in Cotton Sayed Mohsen Mousavi Nik, Hossein. American-Eurasian Journal 
Agriculture \& Environment Science, 10 (4): 653-657.

Trawatha, S.E., Tekrony, D.M., Hidebrand, D.F. (1995). Relationship of soybean seed quality to fatty acid and C Aldehyde levels during storage. Crop Science, 35-1415-1422.

Vertucci, C.W., and E.E. Roos. (1990). Theoretical basis of protocols for seed storage. Plant Physiology, 94: 10191023

Walters, C., 1998. Understanding the mechanisms and kinetics of seed aging. Seed Science Research, 8: 223-244.

Wang, Q. H., Percival, A. E. and Kohel, R. J. (1990) Electrophoretic analysis of seed proteins in Gossypium herbaceum. Jiangsu. Agricultural Science, 5: 12 15 .
Wilson, D.O. Jr and McDonald, M.B. Jr (1986). The lipid peroxidation model of seed ageing. Seed Science Technology, 14, 269-300

Yadav, S.K., Dhankhar, B.S., Deswal, D.P. and Tomar, R.P.S. (2001) Effect of sowing dates and plant geometry on seed production and quality of okra cv. Varsa Uphar. Seed Research, 29 (2): 149 - 152.

Zamani, A., Sadat, N.S.A., Tavakol, A. R., Iran, N.H., Ali, A.G. and Tavakoli A. (2010). Lipid peroxidation and antioxidant enzymes activity under natural and accelerated ageing in safflower (Carthamus tinctorius L.) seed. Iranian Journal Agriculture. Science, 41: 545-554.

\section{How to cite this article:}

Dayal, A., V.S. Mor, O.S. Dahiya and Punia, R.C. 2018. Vigor Evaluation of Fifteen Months Stored Delinted Gossypium hirsutum L. Varieties Picked at Different Intervals. Int.J.Curr.Microbiol.App.Sci. 7(04): 2673-2680. doi: https://doi.org/10.20546/ijcmas.2018.704.305 